\title{
The Polymerization of Acetylenic Derivatives. XXV. Synthesis and Properties of Isomeric Poly( $\beta$-ethynylnaphthalene)
}

\author{
Cr. Simionescu, Sv. Dumitrescu, and V. Percec \\ "Petru Poni" Institute of Macromolecular Chemistry, Jassy-Romania.
}

(Received July 8, 1974)

\begin{abstract}
The polymerization of $\beta$-ethynylnaphthalene with soluble and insoluble Ziegler-Natta catalysts, tertiary phosphine, stibine and arsine-transition metal complexes, as well as by cationic and thermal polymerization has been investigated. The following catalysts, $\mathrm{Me}^{\mathrm{II}}(\mathrm{dmg})_{2} \cdot 2 \mathrm{X} / \mathrm{AlEt}_{3}$ (where $\mathrm{Me}^{\mathrm{II}}=\mathrm{Fe}^{\mathrm{II}}, \mathrm{Ni}{ }^{\mathrm{II}} ; \mathrm{dmg}=$ dimethylglyoxime; $\mathrm{X}=$ Pyridine $(\mathrm{Py})$ or $\mathrm{NH}_{3}$ ), $\mathrm{Me}(\mathrm{acac})_{n} / \mathrm{AlEt}_{3}$ (where $\mathrm{Me}=\mathrm{VO}$ II, $\mathrm{Fe}^{\mathrm{III}}$, $\mathrm{Co}$ III, $\mathrm{Cr}^{\mathrm{III}}$; acac $=$ acetylacetone; $\left.n=2,3\right), \mathrm{TiCl}_{4} / \mathrm{AlEt}_{3}$, specific to cis polymerization of acetylenic monomers and $\left(\mathrm{ZY}_{3}\right)_{a} \cdot \mathrm{MeX}_{b}$ (where $\mathrm{Me}=\mathrm{Rh}, \mathrm{Pd}, \mathrm{Pt}, \mathrm{Ni}, \mathrm{Co} ; \mathrm{X}=\mathrm{Cl}, \mathrm{Br}, \mathrm{I}$, $\mathrm{NO}_{3}, \mathrm{SCN} ; \mathrm{Z}=\mathrm{As}, \mathrm{P}, \mathrm{Sb}$, and $\mathrm{Y}=$ butyl $(\mathrm{Bu})$ or phenyl $\left.(\mathrm{Ph}) ; a=2,3 ; b=2,1\right), \mathrm{Co}\left(\mathrm{NO}_{3}\right)_{2}$. $6 \mathrm{H}_{2} \mathrm{O} / \mathrm{NaBH}_{4}$ and $\mathrm{TiCl}_{4}$ specific to trans polymerization, have been used. The polymers obtained have been analysed from the point of view of their structural and thermal properties. Evidence for three isomeric structures, i.e., cis-transoidal, cis-cisoidal, trans-cisoidal, and the cyclic trimer 1,3,5-tri( $\beta$-naphthyl)benzene has been found. Regarding the cis-cisoidal structure, an exothermal order-disorder transition was observed at $220^{\circ} \mathrm{C}$ indicating an isomerization from the insoluble cis-cisoidal high crystalline structure to the soluble trans-cisoidal amorphous structure.
\end{abstract}

KEY WORDS Poly( $\beta$-ethynylnaphthalene) / Ziegler-Natta Catalyst / Arsine / Stibine / Phosphine Catalyst / Cis-Transoidal / CisCisoidal / Trans-Cisodal / Order-Disorder Transition /

The structure and properties of polyacetylenes obtained with different catalytic systems were investigated by several author groups ${ }^{1-6}$ and some distinctive geometrical isomers have already been pointed out. The presence of the pendent aromatic substituents makes the spectral studies of acetylenic polymers difficult. Although different geometrical structures have already been spectrally demonstrated for polyphenylacetylene $e^{7-10}$ and poly $(\alpha$-ethynylnaphthalene), ${ }^{11}$ in the case of poly( $\beta$-ethynylnaphthalene) (PEN), only the polymer synthesis was reported. ${ }^{12}$

The present paper deals with the synthesis of some of the structural species of PEN for different reaction conditions and catalysts and with a brief characterization of the thermal properties of polymers obtained from EN.

\section{EXPERIMENTAL}

\section{Materials}

$\beta$-Ethynylnaphthalene (EN) was synthesized according to Robin's method ${ }^{13}$ from $\beta$-acetyl naphthalene (AN) by chlorination and subsequent dehydrochlorination of the chlorinated product. AN was prepared by Bassilios's indication $^{14}$ and was recrystallized from ethanol until it contained no $\alpha$ isomer; $\mathrm{mp}=54^{\circ} \mathrm{C}$; IR, $\mathrm{C}=\mathrm{O}$ vibration at $1690 \mathrm{~cm}^{-1}$; $\mathrm{NMR}$ in $\mathrm{CCl}_{4}$ at $20^{\circ} \mathrm{C}, \sigma_{\mathrm{CH}_{3}}=2.62 \mathrm{ppm}, \sigma_{\text {naphthyl }}=7.32-8.20 \mathrm{ppm}$.

The purification and storage of the monomer was achieved through the agency of its silver salt $\left(\nu_{\mathrm{C} \equiv \mathrm{C}}, 2000 \mathrm{~cm}^{-1}\right)$. EN was freshly prepared before use by decomposition of the silver salt with $2-N$ hydrochloric acid, followed by petroleum-ether extraction, neutralization with $\mathrm{Na}_{2} \mathrm{CO}_{3}$ aqueous solution, water washing, drying on anhydrous $\mathrm{CaCl}_{2}$, column chromatography $\left(\mathrm{Al}_{2} \mathrm{O}_{3}\right.$, petroleum-ether eluent $)$, and vacuum drying; $\mathrm{mp}=40.5-41.5^{\circ} \mathrm{C}$. Character- 
istic of the IR spectrum of EN are the bands from 664, 745, 820, 860, and $900 \mathrm{~cm}^{-1}$ (specific to mono-substituted naphtyl), $1600 \mathrm{~cm}^{-1} \quad\left(\nu_{\mathrm{C}=\mathrm{C}}\right.$ aromatic), $2100 \mathrm{~cm}^{-1} \quad\left(\nu_{\mathrm{C} \equiv \mathrm{C}}\right), \quad 3050 \mathrm{~cm}^{-1} \quad\left(\nu_{=} \mathrm{C}-\mathrm{H}\right.$ aromatic), and $3300 \mathrm{~cm}^{-1}\left(\nu_{\equiv \mathrm{C}-\mathrm{H}}\right)$ (Figure 2a). The NMR spectrum of EN $\left(\mathrm{CCl}_{4}\right)$ (Figure $4 \mathrm{a}$ ) exhibits the ethynylic proton resonance at $\sigma=$ $2.97 \mathrm{ppm}$ and the peaks of the aromatic protons at $\sigma=7.20-7.90 \mathrm{ppm}$. The UV spectrum $\left(\mathrm{CH}_{2} \mathrm{Cl}_{2}\right.$ solution) exhibits absorption maxima at $277,286,298,315,325$, and $337 \mathrm{~m} \mu$.

$1,3,5$-Tri( $\beta$-naphthylbenzene), was prepared by condensation of $\beta$-acetyl naphthalene with hydrogen chloride in ethylorthoformate. The product was purified by chromatography $\left(\mathrm{Al}_{2} \mathrm{O}_{3}\right.$, toluene eluent at $80^{\circ} \mathrm{C}$ ) followed by five recrystallizations from toluene; $\mathrm{mp} 244-245^{\circ} \mathrm{C}$, lit. $^{15}$ $\mathrm{mp} 241-242^{\circ} \mathrm{C}$.

Catalytic Systems. $\mathrm{Fe}^{\mathrm{II}}(\mathrm{dmg})_{2} \cdot 2 \mathrm{Py}, \mathrm{Fe}^{\mathrm{II}}(\mathrm{dmg})_{2}$. $2 \mathrm{NH}_{3}$, and $\mathrm{Ni}^{\mathrm{II}}(\mathrm{dmg})_{2}$ were synthesized by Tchugaeff's method, ${ }^{16}$ and $\mathrm{Fe}^{\mathrm{III}}(\mathrm{acac})_{3}, \mathrm{Co}(\mathrm{acac})_{3}, \mathrm{Cr}-$ $(\text { acac })_{3}, \mathrm{VO}(\mathrm{acac})_{2}$ by the usual methods. ${ }^{17} \mathrm{TiCl}_{4}$ and $\mathrm{AlEt}_{3}$ were used as toluene solutions of 1 $\mathrm{mol} / l$ and $6.58 \times 10^{-1} \mathrm{~mol} / l$, respectively. ${ }^{18}$

Phosphine, arsine, and stibine complexes of transition metals from VIII group were prepared by known routes as follows.

$\left(\mathrm{PPh}_{3}\right)_{2} \cdot \mathrm{NiCl}_{2}, \quad\left(\mathrm{PPh}_{3}\right)_{2} \cdot \mathrm{NiBr}_{2}, \quad\left(\mathrm{PPh}_{3}\right)_{2} \cdot \mathrm{NiI}_{2}$, $\left(\mathrm{PPh}_{3}\right)_{2} \cdot \mathrm{Ni}(\mathrm{SCN})_{2}, \quad\left(\mathrm{PPh}_{3}\right)_{2} \cdot \mathrm{Ni}\left(\mathrm{NO}_{3}\right)_{2},{ }^{19} \quad\left(\mathrm{PBu}_{3}\right)_{2}$. $\mathrm{NiCl}_{2},{ }^{20}\left(\mathrm{PPh}_{3}\right)_{2} \cdot \mathrm{CoCl}_{2},{ }^{21}\left(\mathrm{PPh}_{3}\right) \cdot \mathrm{RhCl},{ }^{22}\left(\mathrm{PPh}_{3}\right)_{2}$. $\mathrm{PdCl}_{2},{ }^{23}\left(\mathrm{PBu}_{3}\right)_{2} \cdot \mathrm{PdCl}_{2},{ }^{24}\left(\mathrm{SbPh}_{3}\right)_{2} \cdot \mathrm{PdCl}_{2},\left(\mathrm{AsPh}_{3}\right)_{2}$. $\mathrm{PdCl}_{2}$, and $\left(\mathrm{AsPh}_{3}\right)_{2} \cdot \mathrm{PtCl}_{2} \cdot{ }^{25}$

cis- $\left(\mathrm{PPh}_{3}\right)_{2} \cdot \mathrm{PtCl}_{2}, \quad$ trans- $\left(\mathrm{PPh}_{3}\right)_{2} \cdot \mathrm{PtCl}_{2}, \quad$ and trans- $\left(\mathrm{PPh}_{3}\right)_{2} \cdot \mathrm{Pt}\left(\beta \mathrm{C} \equiv \mathrm{CC}_{10} \mathrm{H}_{7}\right)_{2}$ were synthesized according to the methods reported ${ }^{25,29}$ for similar compounds.

trans- $\left(\mathrm{PPh}_{3}\right)_{2} \cdot \mathrm{Pt}\left(\beta \mathrm{C} \equiv \mathrm{CC}_{10} \mathrm{H}_{7}\right)_{2}$ is a new compound.

The usual method for synthesis of different $\left(\mathrm{PPh}_{3}\right)_{2} \cdot \mathrm{PtCl}_{2}$ isomers are that of Jensen for the cis structure ${ }^{26}$ and Allen for the trans structure. ${ }^{27}$ According to Allen, ${ }^{27}$ trans- $\left(\mathrm{PPh}_{3}\right)_{2} \cdot \mathrm{PtHCl}$ gives a mixture of cis- and trans- $\left(\mathrm{PPh}_{3}\right)_{2} \cdot \mathrm{PtCl}_{2}$. Recently Tayim ${ }^{25}$ synthesized $\left(\mathrm{PPh}_{3}\right) \cdot \mathrm{PtCl}_{2}$ by reacting directly melted $\mathrm{PPh}_{3}$ and $\mathrm{PtCl}_{2}$ and obtained a product identical with that previously reported by Malatesta ${ }^{28}$ by reacting an aqueous solution of $\mathrm{K}_{2} \mathrm{PtCl}_{6}$ with an ethanol solution of $\left(\mathrm{C}_{6} \mathrm{H}_{5}\right)_{3} \mathrm{P}$ at $60^{\circ} \mathrm{C}$. Neither Tayim nor Malatesta reported any information regarding
Table I. UV characteristics of some phosphine complexes

\begin{tabular}{cccl}
\hline Complex & Solvent & $\begin{array}{c}\text { Complex } \\
\text { color }\end{array}$ & $\lambda_{\max }, \mathrm{m} \mu$ \\
\hline trans- $\left(\mathrm{PPh}_{3}\right)_{2} \cdot \mathrm{PtCl}_{2}$ & $\mathrm{CHCl}_{3}$ & Yellow & $320 \mathrm{sh}$ \\
& & & 283 \\
& & & 260 \\
cis- $\left(\mathrm{PPh}_{3}\right)_{2} \cdot \mathrm{PtCl}_{2}$ & $\mathrm{CHCl}_{3}$ & White & 328 \\
& & & $275 \mathrm{sh}$ \\
& & & $267 \mathrm{sh}$ \\
trans- $\left(\mathrm{PPh}_{3}\right)_{2} \cdot$ & $\mathrm{CHCl}_{3}$ & Brown & 270 \\
$\mathrm{Pt}\left(\beta \mathrm{C} \equiv \mathrm{CC}_{10} \mathrm{H}_{7}\right)_{2}$ & & & $298 \mathrm{sh}$ \\
& & & $309 \mathrm{sh}$ \\
& & & $348 \mathrm{sh}$ \\
& & & 367 \\
trans- $\left(\mathrm{PPh}_{3}\right)_{2} \cdot$ & $\mathrm{CH}_{2} \mathrm{Cl}_{2}$ & Brown & 255 \\
$\mathrm{Pt}\left(\beta \mathrm{C} \equiv \mathrm{CC}_{10} \mathrm{H}_{7}\right)_{2}$ & & & 270 \\
& & & 307 \\
& & & $340 \mathrm{sh}$ \\
& & & 363 \\
\hline
\end{tabular}

the product geometry.

In the present work $\left(\mathrm{PPh}_{3}\right)_{2} \cdot \mathrm{PtCl}_{2}$ was synthesized by Tayim's method ${ }^{25}$ obtaining a white product having a cis structure. According to Tayim's method ${ }^{29}$ (in solution) a yellow $\left(\mathrm{PPh}_{3}\right)_{2}$. $\mathrm{PtCl}_{2}$ complex of trans structure was synthesized. The compounds were identified by their UV and IR spectra. In the $625-3800 \mathrm{~cm}^{-1}$ region, the IR spectra are identical for both compounds. The UV spectra present specific trans maxima to yellow and specific cis maxima to white compounds $^{30}$ (Table I).

trans- $\left(P P h_{3}\right)_{2} \cdot P t\left(\beta C \equiv C_{10} H_{7}\right)_{2} . \quad$ A suspension of sodamide was prepared in a small Dewar vessel from sodium $(0.23 \mathrm{~g})$, liquid ammonia $(50 \mathrm{ml})$. $\beta$-Ethynylnaphthalene $(1.5 \mathrm{~g})$ and cis$\left(\mathrm{PPh}_{3}\right)_{2} \cdot \mathrm{PtCl}_{2}(0.8 \mathrm{~g})$ were added. After $20 \mathrm{~min}$ of intermittent stirring, dry ammonium chloride $(1 \mathrm{~g})$ was added and the ammonia was evaporated off. The crude solid treated with $\mathrm{CHCl}_{3}$ and precipitated with $\mathrm{CH}_{3} \mathrm{OH}$ gave trans- $\left(\mathrm{PPh}_{3}\right)_{2}$. $\mathrm{Pt}\left(\beta \mathrm{C} \equiv \mathrm{CC}_{10} \mathrm{H}_{7}\right)_{2}$. The product is light brown, $\mathrm{mp} 240-242^{\circ} \mathrm{C}$. The IR spectrum of trans$\left(\mathrm{PPh}_{3}\right)_{2} \cdot \mathrm{Pt}\left(\beta \mathrm{C} \equiv \mathrm{CC}_{10} \mathrm{H}_{7}\right)_{2}$ is characterized by $\mathrm{C} \equiv \mathrm{C}$ stretching vibration at $2100 \mathrm{~cm}^{-1}$. UV data are given in Table I.

\section{Polymerization}

The polymerization of EN with soluble Ziegler catalysts was carried out in $50-100-\mathrm{m} l$ joint-cap 
bottles in a nitrogen atmosphere. The addition sequence for the $\mathrm{Me}^{\mathrm{II}}(\mathrm{dmg})_{2} \cdot 2 \mathrm{X} / \mathrm{AlEt}_{3}$ and $\mathrm{Me}(\mathrm{acac})_{n} / \mathrm{AlEt}_{3}$ (chelate compound, $\mathrm{AlEt}_{3}$, solvent, and monomer) was maintained the same for all experiments. After introduction of $\mathrm{AlEt}_{3}$ and solvent, the reaction mixture was kept at $90^{\circ} \mathrm{C}$ for $15 \mathrm{~min}$ in order to obtain the active species. Then the bottles were put in a Dry-Ice bath and the monomer added. All the polymerizations have been carried out in a water bath at $20 \pm 0.1^{\circ} \mathrm{C}$.

In the case of polymerizations with $\mathrm{TiCl}_{4} /$ $\mathrm{AlEt}_{3}$, the addition sequence was: $\mathrm{AlEt}_{3}, \mathrm{TiCl}_{4}$, solvent and monomer, and for $\mathrm{Co}\left(\mathrm{NO}_{3}\right)_{2} \cdot 6 \mathrm{H}_{2} \mathrm{O}$ / $\mathrm{NaBH}_{4}$ catalyst, the sequence was $\mathrm{Co}\left(\mathrm{NO}_{3}\right)_{2}$. $6 \mathrm{H}_{2} \mathrm{O}$, EtOH, monomer, and $\mathrm{NaBH}_{4}$.

The polymerizations with phosphine, arsine, and stibine catalysts were carried out in bulk (air atmosphere) and the contents were magnetically stirred. Open bottles provided with a condenser containing the reaction mixture were immersed in oil bath of $140 \pm 1^{\circ} \mathrm{C}$.

After the required time had elapsed, the catalytic systems were destroyed with $10-\% \mathrm{HCl}$ methanolic solution (at a temperature lower than that of the polymerization reaction). Three fractions were then isolated: one insoluble in benzene (I), one soluble in benzene but insoluble in large amounts of methanol (II) and the last one insoluble in methanol: water $(3: 1$, vol ratio) mixture (III). The benzene-insoluble fraction (I) was repeatedly washed with concentrated $\mathrm{HCl}$ solution in order to remove the catalyst traces, then neutralized with $\mathrm{Na}_{2} \mathrm{CO}_{3}$ aqueous solution and washed with water, methanol, and finally with benzene. The benzene-soluble fractions (II) and (III) were purified by methanol (or methanol-water mixture) reprecipitation from benzene solutions. The polymers were then dried at $40^{\circ} \mathrm{C}$ in vacuo for $24 \mathrm{hr}$.

\section{Polymer Characterization}

The average molecular weights were determined by a cryoscopic method (polymer solution in benzene). ${ }^{31}$

The softening intervals were read on a Boetius apparatus.

Qualitative infrared spectra were run on a UNICAM SP-200 spectrophotometer ( $\mathrm{KBr}$ pellet) and the electronic spectra were recorded on a UNICAM SP-800 UV spectrophotometer.

Nuclear magnetic resonance (JEOL-60-MHz) spectra were obtained using $\mathrm{CCl}_{4}$ or $\mathrm{CDCl}_{3}$ as solvent and tetramethylsilane as internal standard.

Thermogravimetric analyses were performed on a Paulik-Paulik-Erdey (Budapest) analyser for measurements carried out in air. A Mettler balance was used for measurements carried out in inert atmosphere (nitrogen).

X-Ray diffractions (XRD) were carried out on a Kristalloflex Siemens $\left(\mathrm{CuK}_{\alpha}\right)$ equipment.

\section{RESULTS AND DISCUSSION}

\section{$\beta$-Ethynylnaphthalene Polymerization}

By polymerization of EN with modified soluble Ziegler catalysts, i.e., $\mathrm{Me}^{\mathrm{II}}(\mathrm{dmg})_{2} \cdot 2 \mathrm{X} / \mathrm{AlEt}_{3}$, $\mathrm{Me}(\mathrm{acac})_{n} / \mathrm{AlEt}_{3}$ and with insoluble Ziegler catalysts, i.e., $\mathrm{TiCl}_{4} / \mathrm{AlEt}_{3}$, a red benzene-insoluble polymer (B), and a yellow-brown benzene-soluble polymer (C) were separated (Table II).

The ratio of (B) and (C) polymer fractions depends on the Me nature in the case of catalytic systems $\mathrm{Me}(\mathrm{acac})_{n} / \mathrm{AlEt}_{3}$. It can be seen in Table II that this ratio is greater than one for $\mathrm{Me}=\mathrm{VO}, \mathrm{Fe}^{\mathrm{III}}$ and $\mathrm{Cr}$, and smaller than one for $\mathrm{Me}=\mathrm{Co}$. The same values for (B) $v s$. (C) ratio were obtained in the polymerization of phenylacetylene and $N$-ethynyl carbazole. ${ }^{43}$ For the same catalytic system, the (B) $v s$. (C) ratio is a function of the $\mathrm{Al} v s$. Me ratio, e.g., for $\mathrm{Fe}^{\mathrm{II}}(\mathrm{dmg})_{2} \cdot 2 \mathrm{Py} / \mathrm{AlEt}_{3}$ the maximum yield of (B) is obtained for a molar ratio of $\mathrm{Al} / \mathrm{Fe}=13$ (Table II).

The polymer $(\mathrm{C})$ was divided into two fractions. A brown fraction insoluble in methanol (II) and a yellow fraction (III) soluble in methanol but insoluble in the methanol-water $(3: 1)$ mixture, the IR spectrum of both fractions being identical.

The fraction (A) could be isolated only if the polymerization was carried out at $0^{\circ} \mathrm{C}$ (No. 21, II, Table II). This fraction is soluble in benzene and during its dissolution for purifying by reprecipitation it isomerized to an insoluble polymer type (B).

For the polymerizations carried out with $\mathrm{Fe}^{\mathrm{II}}(\mathrm{dmg})_{2} \cdot 2 \mathrm{Py} / \mathrm{AlEt}_{3}$, the optimal conditions are listed in Table II: $\mathrm{Al} / \mathrm{Fe}=13, \mathrm{Fe}^{\mathrm{II}}(\mathrm{dmg})_{2} \cdot 2 \mathrm{Py}=$ $5 \%$, solvent/monomer ratio, 5 (vol). In the 
Table II. Polymerization of $\beta$-ethynylnaphthalene with some Ziegler-Natta catalytic systems and with $\mathrm{TiCl}_{4}$ : volumetric ratio, (solvent $\left.+\mathrm{AlEt}_{3}\right) /$ monomer $=5$; solvent, toluene; temp, $20^{\circ} \mathrm{C}$; time, $24 \mathrm{hr}^{\mathrm{a}}$

\begin{tabular}{|c|c|c|c|c|c|c|c|c|c|c|c|c|}
\hline \multirow{2}{*}{ No. } & \multirow{2}{*}{ Catalyst } & \multicolumn{2}{|c|}{$\begin{array}{l}\text { Cocatalyst } \\
\text { molar ratio }\end{array}$} & \multicolumn{4}{|c|}{ Polymerization yield, $\%^{\mathrm{b}}$} & \multicolumn{3}{|c|}{ Softening temp, ${ }^{\circ} \mathrm{C}$} & \multicolumn{2}{|c|}{$\bar{M}_{n}$} \\
\hline & & $\begin{array}{c}\text { Molar } \\
\%\end{array}$ & $\begin{array}{l}\text { Cat/ } \\
\text { Cocat }\end{array}$ & Total & $\begin{array}{l}\text { I } \\
(\mathbf{B})\end{array}$ & $\underset{(\mathrm{C})}{\mathrm{II}}$ & $\underset{(\mathrm{CI})}{ }$ & $\begin{array}{c}\text { I } \\
(\mathbf{B})\end{array}$ & II & $\underset{(\mathrm{CI})}{ }$ & $\underset{(\mathrm{C})}{ }$ & III \\
\hline 1 & $\mathrm{AlEt}_{3} / \mathrm{VO}(\mathrm{acac})_{2}$ & 5 & 3 & 62.64 & 41.66 & Trace & 20.98 & $248-50$ & - & $128-30$ & - & 490 \\
\hline 2 & $\mathrm{AlEt}_{3} / \mathrm{Cr}(\mathrm{acac})_{3}$ & 5 & 3 & 3.60 & 3.60 & Trace & Trace & $254-56$ & - & - & - & - \\
\hline 3 & $\mathrm{AlEt}_{3} / \mathrm{Co}(\mathrm{acac})_{3}$ & 5 & 3 & 49.80 & 17.76 & Trace & 32.04 & $240-243$ & - & $115-18$ & - & 463 \\
\hline 4 & $\mathrm{AlEt}_{3} / \mathrm{Fe}(\mathrm{acac})_{3}$ & 5 & 3 & 56.78 & 52.12 & Trace & 4.66 & $250-52$ & - & $145-47$ & - & 583 \\
\hline 5 & $\mathrm{AlEt}_{3} / \mathrm{Ni}(\mathrm{dmg})_{2}$ & 5 & 10 & Trace & Trace & - & - & - & - & - & - & - \\
\hline 6 & $\mathrm{AlEt}_{3} / \mathrm{Fe}(\mathrm{dmg})_{2} \cdot 2 \mathrm{NH}_{3}$ & 5 & 13 & - & - & - & - & - & - & - & - & - \\
\hline 7 & $\mathrm{AlEt}_{3} / \mathrm{Fe}(\mathrm{dmg})_{2} \cdot 2 \mathrm{Py}$ & 1 & 2.6 & 8.66 & 4.34 & Trace & 4.32 & - & - & $170-74$ & - & 720 \\
\hline 8 & $\mathrm{AlEt}_{3} / \mathrm{Fe}(\mathrm{dmg})_{2} \cdot 2 \mathrm{Py}$ & 1 & 5.2 & 12.62 & 3.36 & Trace & 9.26 & $247-50$ & - & $148-50$ & - & 620 \\
\hline 9 & $\mathrm{AlEt}_{3} / \mathrm{Fe}(\mathrm{dmg})_{2} \cdot 2 \mathrm{Py}$ & 1 & 7.8 & 20.10 & 14.04 & Trace & 6.06 & $250-52$ & - & $125-27$ & - & 532 \\
\hline 10 & $\mathrm{AlEt}_{3} / \mathrm{Fe}(\mathrm{dmg})_{2} \cdot 2 \mathrm{Py}$ & 1 & 10.4 & 22.90 & 8.72 & Trace & 14.18 & $244-45$ & - & $128-31$ & - & 547 \\
\hline 11 & $\mathrm{AlEt}_{3} / \mathrm{Fe}(\mathrm{dmg})_{2} \cdot 2 \mathrm{Py}$ & 1 & 13.0 & 48.19 & 35.34 & Trace & 12.85 & $244-46$ & - & $125-27$ & - & 520 \\
\hline 12 & $\mathrm{AlEt}_{3} / \mathrm{Fe}(\mathrm{dmg})_{2} \cdot 2 \mathrm{Py}$ & 1 & 15.6 & 41.60 & 25.60 & Trace & 16.00 & $246-47$ & 一 & $110-15$ & - & 490 \\
\hline 13 & $\mathrm{AlEt}_{3} / \mathrm{Fe}(\mathrm{dmg})_{2} \cdot 2 \mathrm{Py}$ & 5 & 13.0 & 70.28 & 58.90 & Trace & 11.38 & $246-47$ & - & $138-40$ & - & 632 \\
\hline 14 & $\mathrm{AlEt}_{3} / \mathrm{Fe}(\mathrm{dmg})_{2} \cdot 2 \mathrm{Py}$ & $5(a)$ & 13.0 & 60.50 & 42.86 & Trace & 17.64 & $234-36$ & - & $145-47$ & - & 700 \\
\hline 15 & $\mathrm{AlEt}_{3} / \mathrm{Fe}(\mathrm{dmg})_{2} \cdot 2 \mathrm{Py}$ & $10(b)$ & 13.0 & 38.46 & 28.64 & Trace & 9.82 & $233-34$ & - & - & - & - \\
\hline 16 & $\mathrm{AlEt}_{3} / \mathrm{Fe}(\mathrm{dmg})_{2} \cdot 2 \mathrm{Py}$ & $5(\mathrm{c})$ & 13.0 & 38.69 & 29.96 & 1.51 & 7.22 & $234-35$ & $210-15$ & $115-18$ & 2087 & 485 \\
\hline 17 & $\mathrm{AlEt}_{3} / \mathrm{Fe}(\mathrm{dmg})_{2} \cdot 2 \mathrm{Py}$ & $5(d)$ & 13.0 & 67.76 & 40.36 & 6.40 & 21.00 & $235-36$ & $178-80$ & $112-15$ & - & 525 \\
\hline 18 & $\mathrm{AlEt}_{3} / \mathrm{Fe}(\mathrm{dmg})_{2} \cdot 2 \mathrm{Py}$ & $5(\mathrm{e})$ & 13.0 & 61.40 & 38.88 & 5.99 & 16.53 & $242-44$ & $205-10$ & $134-35$ & 2053 & 620 \\
\hline 19 & $\mathrm{AlEt}_{3} / \mathrm{Fe}(\mathrm{dmg})_{2} \cdot 2 \mathrm{Py}$ & $5(f)$ & 13.0 & 64.10 & 41.08 & 2.30 & 20.72 & $235-36$ & $185-87$ & $105-07$ & - & 531 \\
\hline 20 & $\mathrm{AlEt}_{3} / \mathrm{Fe}(\mathrm{dmg})_{2} \cdot 2 \mathrm{Py}$ & $5(\mathrm{~g})$ & 13.0 & Trace & Trace & - & - & - & - & - & - & - \\
\hline 21 & $\mathrm{AlEt}_{3} / \mathrm{Fe}(\mathrm{dmg})_{2} \cdot 2 \mathrm{Py}$ & $5(\mathrm{~h})$ & 13.0 & 16.14 & 一 & Trace $^{c}$ & - & $239-40$ & - & - & - & - \\
\hline 22 & $\mathrm{AlEt}_{3} / \mathrm{TiCl}_{4}$ & 5 & 2.3 & 94.73 & - & 67.77 & 26.96 & - & $132-35$ & $98-100$ & 583 & 497 \\
\hline 23 & $\mathrm{AlEt}_{3} / \mathrm{TiCl}_{4}$ & 5 & 8 & 100.00 & Trace & 75.47 & 24.53 & - & $150-55$ & $94-95$ & 820 & 492 \\
\hline 24 & $\mathrm{AlEt}_{3} / \mathrm{TiCl}_{4}$ & $5(\mathrm{i})$ & 8 & 68.12 & Trace & 45.11 & 23.01 & - & - & 一 & - & - \\
\hline 25 & $\mathrm{AlEt}_{3} / \mathrm{TiCl}_{4}$ & $5(j)$ & 8 & Trace & - & - & Trace & - & - & - & - & - \\
\hline 26 & $\mathrm{TiCl}_{4}$ monomer $/ \mathrm{TiCl}_{4}=10$ & $1(\mathrm{k})$ & - & 25.00 & - & 13.0 & 12.0 & - & $163-65$ & - & 720 & - \\
\hline 27 & $\mathrm{Co}\left(\mathrm{NO}_{3}\right)_{2} \cdot 6 \mathrm{H}_{2} \mathrm{O}$ & $10(1)$ & 1.0 & 37.00 & - & 30.3 & 6.7 & - & - & - & - & - \\
\hline
\end{tabular}

In all the polymerizations the monomer was added at $-78^{\circ} \mathrm{C}$.

b I, benzene-insoluble polymer fraction; II, methanol-insoluble polymer fraction; III, 3/1 methanol-water insoluble polymer fraction; (B), polymer (B); (C), polymer (C).

c Polymer (A).

(a), volumetric ratio, (solvent $\left.+\mathrm{AlEt}_{3}\right) /$ monomer $=10$; (b), ibidem; (c), monomer was added at $20^{\circ} \mathrm{C} ;$ time, $4 \mathrm{hr} ;(\mathrm{d})$, time, $4 \mathrm{hr} ;(\mathrm{e}), 2 \mathrm{hr}$ at $-78^{\circ} \mathrm{C}, 2 \mathrm{hr}$ at $20^{\circ} \mathrm{C}$, total time $4 \mathrm{hr} ;(\mathrm{f}), 1 \mathrm{hr}$ at $-78^{\circ} \mathrm{C}, 3 \mathrm{hr}$ at $20^{\circ} \mathrm{C}$, total time $4 \mathrm{hr} ;(\mathrm{g})$, polymerization at $-78^{\circ} \mathrm{C} ;(\mathrm{h})$, polymerization at $0^{\circ} \mathrm{C} ;$ $\overrightarrow{6}$ time, $4 \mathrm{hr}$; (i), $2 \mathrm{hr}$ at $-78^{\circ} \mathrm{C}, 2 \mathrm{hr}$ at $20^{\circ} \mathrm{C}$, total time $4 \mathrm{hr} ;(\mathrm{j})$, total time $4 \mathrm{hr}$ at $-78^{\circ} \mathrm{C} ;(\mathrm{k})$, volumetric ratio, solvent $/ \mathrm{monomer}=20 / 1 ;$ time, $6 \mathrm{hr} ;(1)$, solvent $(\mathrm{EtOH}) /$ monomer, $20 / 1$; time $36 \mathrm{hr}$. 
Table III. Polymerization of $\beta$-ethynylnaphthalene with phosphine, arsine, and stibine complexes of transition metals of VIII group: temp, $140^{\circ} \mathrm{C}$; time, $6 \mathrm{hr}$; catalyst concn, $5 \%$; bulk polymerization

\begin{tabular}{|c|c|c|c|c|c|c|c|c|}
\hline \multirow{2}{*}{ No. } & \multirow{2}{*}{ Catalyst } & \multicolumn{3}{|c|}{ Polymerization yield, $\%^{a}$} & \multicolumn{2}{|c|}{$\begin{array}{l}\text { Softening } \\
\text { temp, }{ }^{\circ} \mathrm{C}\end{array}$} & \multicolumn{2}{|c|}{$\bar{M}_{n}$} \\
\hline & & Total & $\stackrel{\text { II }}{(\mathrm{C})}$ & $\underset{(\mathrm{CI})}{ }$ & $\stackrel{\text { II }}{(\mathrm{C})}$ & $\stackrel{\mathrm{mI}}{(\mathrm{C})}$ & $\stackrel{\mathrm{II}}{(\mathrm{C})}$ & $\underset{(\mathrm{CI})}{(\mathrm{II}}$ \\
\hline 28 & Thermal polymn & 38.90 & 21.70 & 17.20 & $194-96$ & $115-18$ & 1435 & 540 \\
\hline 29 & $\left(\mathrm{PPh}_{3}\right)_{2} \cdot \mathrm{CoCl}_{2}$ & 54.61 & 42.70 & 11.91 & $212-14$ & $158-60$ & 2100 & 760 \\
\hline 30 & $\left(\mathrm{PPh}_{3}\right)_{2} \cdot \mathrm{NiCl}_{2}$ & 88.04 & 68.84 & 19.20 & $182-85$ & $109-10$ & 1625 & 500 \\
\hline 31 & $\left(\mathrm{PPh}_{3}\right)_{2} \cdot \mathrm{NiBa}_{2}$ & 94.70 & 74.33 & 20.37 & $200-05$ & $138-40$ & 1930 & 620 \\
\hline 32 & $\left(\mathrm{PPh}_{3}\right)_{2} \cdot \mathrm{NiI}_{2}$ & 96.42 & 71.30 & 24.12 & $174-75$ & $125-29$ & 1525 & 632 \\
\hline 33 & $\left(\mathrm{PPh}_{3}\right)_{2} \cdot \mathrm{Ni}(\mathrm{SCN})_{2}$ & 79.49 & 64.99 & 14.50 & $171-72$ & $128-30$ & 1235 & 620 \\
\hline 34 & $\left(\mathrm{PPh}_{3}\right)_{2} \cdot \mathrm{Ni}\left(\mathrm{NO}_{3}\right)_{2}$ & 86.03 & 74.10 & 11.93 & $200-02$ & $123-25$ & 1920 & 590 \\
\hline 35 & $\left(\mathrm{PBu}_{3}\right)_{2} \cdot \mathrm{NiCl}_{2}$ & 99.99 & 92.02 & 7.97 & $160-65$ & $108-10$ & 1025 & 520 \\
\hline 36 & $\left(\mathrm{PPh}_{3}\right)_{2} \cdot \mathrm{RhCl}$ & 93.89 & 69.51 & 24.38 & $152-54$ & $112-14$ & 835 & 500 \\
\hline 37 & $\left(\mathrm{PPh}_{3}\right)_{2} \cdot \mathrm{PdCl}_{2}$ & 89.98 & 74.58 & 15.40 & $158-59$ & $138-40$ & 870 & 592 \\
\hline 38 & $\left(\mathrm{PBu}_{3}\right)_{2} \cdot \mathrm{PdCl}_{2}$ & 100.00 & 95.63 & 4.37 & $168-70$ & $125-27$ & 925 & 512 \\
\hline 39 & $\left(\mathrm{SbPh}_{3}\right)_{2} \cdot \mathrm{PdCl}_{2}$ & 81.33 & 66.64 & 14.69 & $175-77$ & $135-37$ & 930 & 530 \\
\hline 40 & $\left(\mathrm{AsPh}_{3}\right)_{2} \cdot \mathrm{PdCl}_{2}$ & 93.83 & 79.85 & 13.98 & $179-81$ & $138-39$ & 890 & 542 \\
\hline 41 & $c i s-\left(\mathrm{PPh}_{3}\right)_{2} \cdot \mathrm{PtCl}_{2}$ & 87.60 & 73.69 & 13.91 & $169-71$ & $123-25$ & 725 & 513 \\
\hline 42 & trans $-\left(\mathrm{PPh}_{3}\right)_{2} \cdot \mathrm{PtCl}_{2}$ & 91.61 & 78.13 & 13.48 & $165-67$ & $145-46$ & 842 & 603 \\
\hline 43 & trans $-\left(\mathrm{PPh}_{3}\right)_{2} \cdot \mathrm{Pt}\left(\beta \mathrm{C} \equiv \mathrm{CC}_{10} \mathrm{H}_{7}\right)_{2}$ & 98.12 & 82.11 & 16.01 & $225-27$ & $180-82$ & 1500 & 820 \\
\hline 44 & $\left(\mathrm{AsPh}_{3}\right)_{2} \cdot \mathrm{PtCl}_{2}$ & 96.69 & 80.10 & 16.59 & $173-75$ & $130-32$ & 1025 & 535 \\
\hline
\end{tabular}

a II, methanol-insoluble polymer fraction; III, 3:1 methanol-water polymer insoluble fraction; (C), polymer (C).

case of the polymerization with $\mathrm{Co}\left(\mathrm{NO}_{3}\right)_{2} \cdot 6 \mathrm{H}_{2} \mathrm{O} /$ $\mathrm{NaBH}_{4}$, only a yellow-brown soluble polymer of type (C) was obtained (Table II).

The cationic $\left(\mathrm{TiCl}_{4}\right)$ and thermal polymerizations and polymerizations carried out in presence of phosphine, arsine, and stibine complexes gave the same type of polymer, i.e., type (C) (Tables II, III).

In the last case, the reactivity of the catalysts decreases as follows: for $\mathrm{Me}, \mathrm{Rh}>\mathrm{Pt}>\mathrm{Pd}>$ $\mathrm{Ni}>\mathrm{Co}$; for $\mathrm{X}, \mathrm{I}>\mathrm{Br}>\mathrm{Cl}>\mathrm{NO}_{3}>\mathrm{SCN}$; for $\mathrm{Z}$, $\mathrm{As}>\mathrm{P}>\mathrm{Sb}$ and for $\mathrm{Y}, \mathrm{Bu}>\mathrm{Ph}$. The polymerizations with cis- and trans- $\left(\mathrm{PPh}_{3}\right)_{2} \cdot \mathrm{PtCl}_{2}$ were followed by taking off periodically samples of the mixture and by their subsequent chromatographing on silica gel columns using $\mathrm{C}_{6} \mathrm{H}_{6} / \mathrm{CHCl}_{3}$ $(1: 1)$ as eluent. The separated products were identified by their UV spectra and showed the presence of trans- $\left(\mathrm{PPh}_{3}\right)_{2} \cdot \mathrm{Pt}\left(\beta \mathrm{C} \equiv \mathrm{CC}_{10} \mathrm{H}_{7}\right)_{2}$ in the initiation step. Higher yields obtained in the case of EN polymerization with trans- $\left(\mathrm{PPh}_{3}\right)_{2}$. $\mathrm{Pt}\left(\beta \mathrm{C} \equiv \mathrm{CC}_{10} \mathrm{H}_{7}\right)_{2}$ as compared with cis- and trans$\left(\mathrm{PPh}_{3}\right)_{2} \cdot \mathrm{PtCl}_{2}$ and the presence of trans- $\left(\mathrm{PPh}_{3}\right)_{2}$.
$\mathrm{Pt}\left(\beta \mathrm{C} \equiv \mathrm{CC}_{10} \mathrm{H}_{7}\right)_{2}$ during polymerization process, support the already proposed reaction mechanism. ${ }^{11}$

The nature of $\mathrm{X}$ influences the rate of $\left(\mathrm{PPh}_{3}\right)_{2}$. $\operatorname{Pt}\left(\beta \mathrm{C} \equiv \mathrm{CC}_{10} \mathrm{H}_{7}\right)_{2}$ formation. Trans- $\left(\mathrm{PPh}_{3}\right)_{2}$. $\operatorname{Pt}\left(\beta \mathrm{C} \equiv \mathrm{CC}_{10} \mathrm{H}_{7}\right)_{2}$ contains a conjugated electronic system $^{32}$ obtained by interaction of $\pi$ orbitals from ethynyl groups and $d_{\mathrm{xy}}$ and $d_{\mathrm{yz}}$ metal orbitals. The metal acts as an electron-donor to the ethynyl groups by back-donation so that the ethynyl groups become electron-donors. The metal nature problably changes the ionization energy of trans- $\left(\mathrm{PPh}_{3}\right)_{2} \cdot \mathrm{Me}\left(\beta \mathrm{C} \equiv \mathrm{CC}_{10} \mathrm{H}_{7}\right)_{2}$. It is possible in this way to obtain a weak charge transfer complex between $p_{z}$ metal orbital from trans- $\left(\mathrm{PPh}_{3}\right)_{2} \cdot \mathrm{Pt}\left(\beta \mathrm{C} \equiv \mathrm{CC}_{10} \mathrm{H}_{7}\right)_{2}$ and acetylenic monomer. The order determined for the reactivity imprimed by metal is in good agreement with the equilibrium constants found by Masai ${ }^{33}$ for some charge-transfer complexes of $\left(\mathrm{ZY}_{3}\right)_{2}$. $\mathrm{Me}^{\mathrm{II}}(\mathrm{C} \equiv \mathrm{CR})_{2}$ and TCNQ type.

Poly( $\beta$-ethynylnaphthalene) Structure

All poly( $\beta$-ethynylacetylene) (PEN) infrared 


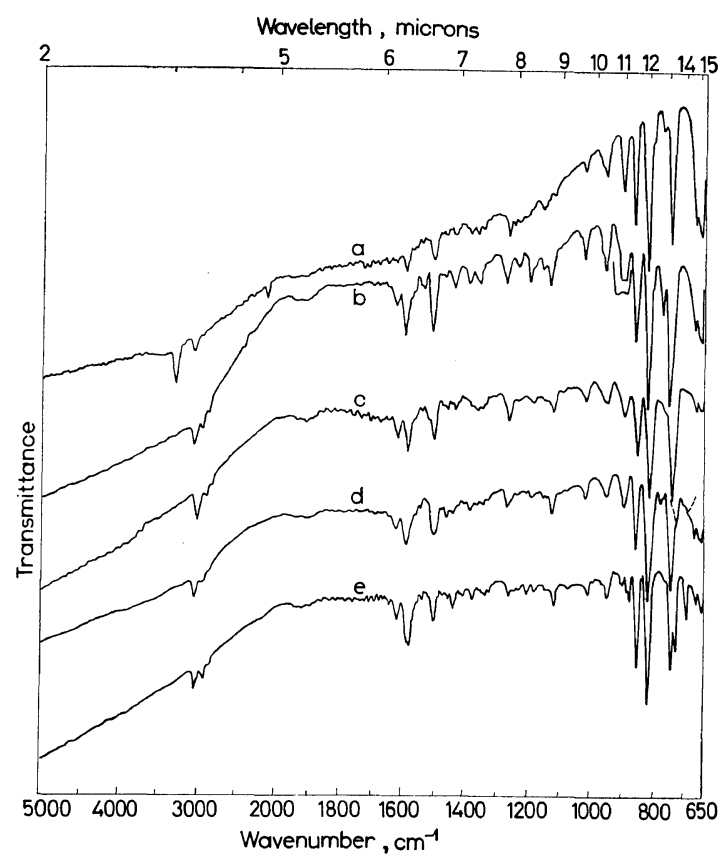

Figure 1. IR spectra: a, $\beta$-ethynylnaphthalene; b, typical PEN cis-cisoidal structure (B); c, typical PEN trans-cisoidal structure (C); d, typical 1,3,5cyclic trimer separated by chromatography; e, 1,3,5-tri( $\beta$-naphthyl)benzene.

spectra (Figures $1 \mathrm{~b}$ and $1 \mathrm{c}$ ) present a new band at $1620 \mathrm{~cm}^{-1}$ owing to conjugated double bonds from the polymer chain as well as the band from $1600 \mathrm{~cm}^{-1}$ assigned to conjugated double bonds of naphthalene ring.

The IR spectrum of polymer (B) (Figure 1b) shows a band at $785 \mathrm{~cm}^{-1}$ due to $\mathrm{C}-\mathrm{H}$ outof-plane deformation in the cis structure, by analogy with similar deformations met in cis polyacetylene, ${ }^{4-6}$ cis polyphenylacetylene, ${ }^{7,8}$ cis poly(2-phenyl-1,3-butadiene) ${ }^{34}$ and cis poly $(\alpha-$ ethynyl naphthalene). ${ }^{11}$ The IR spectrum of polymer (C) does not have the band from 785 $\mathrm{cm}^{-1}$. In addition to the IR spectrum of the polymer $(\mathrm{C})$, two bands could be found in the IR spectrum of the polymer (B), at 1420 and $1390 \mathrm{~cm}^{-1}$. By analogy with the spectra of cis polyacetylene, ${ }^{6}$ these new bands could be ascribed to cis $\mathrm{C}-\mathrm{H}$ in-plane vibration. At the same time the absorption from $905 \mathrm{~cm}^{-1}$ exhibited by the polymer (C), dissappears in the IR spectrum of polymer (B) which shows two bands at 900 and $920 \mathrm{~cm}^{-1}$. Some unassigned differences in this domain $\left(900 \mathrm{~cm}^{-1}\right)$ were pointed out also in the IR spectra of cis and trans polyphenylacetylene. ${ }^{7,8}$

XRD presents for polymer (B) a high degree of crystallinity $(60 \%)$ as compared with polymer

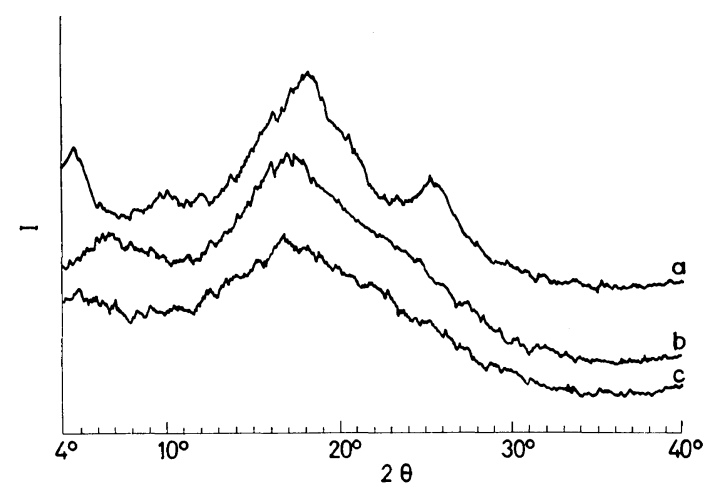

Figure 2. Some typical XRD spectra: a, high crystalline cis-cisoidal PEN structure (No. $16 \mathrm{I}$ ); b, low crystalline trans-cisoidal structure (No. 22 II); c, amorphous trans-cisoidal PEN structure (No. $28 \mathrm{II})$.

Table IV. Crystallinity degree of some $\beta$-ethynylnaphthalene polymers

\begin{tabular}{|c|c|c|c|}
\hline $\begin{array}{l}\text { No. from } \\
\text { Table II } \\
\text { or III }\end{array}$ & Catalyst & Structure $^{a}$ & $\begin{array}{c}\text { Crystal- } \\
\text { linity } \\
\text { degree, } \\
\%\end{array}$ \\
\hline $28 \mathrm{II}$ & Thermal & $\mathrm{t}-\mathrm{c}$ & Amorph \\
\hline $28 \mathrm{III}$ & Thermal & $\mathrm{t}-\mathrm{c}$ & Amorph \\
\hline $26 \mathrm{II}$ & $\mathrm{TiCl}_{4}$ & $\mathrm{t}-\mathrm{c}$ & 10 \\
\hline 31 II & $\left(\mathrm{PPh}_{3}\right)_{2} \cdot \mathrm{NiBr}_{2}$ & $\mathrm{t}-\mathrm{c}$ & 19 \\
\hline $31 \mathrm{III}$ & $\left(\mathrm{PPh}_{3}\right)_{2} \cdot \mathrm{NiBr}_{2}$ & $t-c$ & 8 \\
\hline $35 \mathrm{II}$ & $\left(\mathrm{PBu}_{3}\right)_{2} \cdot \mathrm{NiCl}_{2}$ & $\mathrm{t}-\mathrm{c}$ & 20 \\
\hline $38 \mathrm{II}$ & $\left(\mathrm{PBu}_{3}\right)_{2} \cdot \mathrm{PdCl}_{2}$ & $\mathrm{t}-\mathrm{c}$ & 17 \\
\hline $22 \mathrm{II}$ & $\mathrm{AlEt}_{3} / \mathrm{TiCl}_{4}$ & $\mathrm{t}-\mathrm{c}$ & 18 \\
\hline $22 \mathrm{III}$ & $\mathrm{AlEt}_{3} / \mathrm{TiCl}_{4}$ & $\mathrm{t}-\mathrm{c}$ & 11 \\
\hline $23 \mathrm{II}$ & $\mathrm{AlEt}_{3} / \mathrm{TiCl}_{4}$ & $t-c$ & Amorph \\
\hline $23 \mathrm{III}$ & $\mathrm{AlEt}_{3} / \mathrm{TiCl}_{4}$ & $\mathrm{t}-\mathrm{c}$ & Amorph \\
\hline $18 \mathrm{III}$ & $\mathrm{AlEt}_{3} / \mathrm{Fe}(\mathrm{dmg})_{2} \cdot 2 \mathrm{Py}$ & $t-c$ & 11 \\
\hline $18 \mathrm{I}$ & $\mathrm{AlEt}_{3} / \mathrm{Fe}(\mathrm{dmg})_{2} \cdot 2 \mathrm{Py}$ & $\mathrm{c}-\mathrm{c}$ & 62 \\
\hline $14 \mathrm{I}$ & $\mathrm{AlEt}_{3} / \mathrm{Fe}(\mathrm{dmg})_{2} \cdot 2 \mathrm{Py}$ & $\mathrm{c}-\mathrm{c}$ & 66 \\
\hline $16 \mathrm{I}$ & $\mathrm{AlEt}_{3} / \mathrm{Fe}(\mathrm{dmg})_{2} \cdot 2 \mathrm{Py}$ & c-c & 60 \\
\hline $19 \mathrm{I}$ & $\mathrm{AlEt}_{3} / \mathrm{Fe}(\mathrm{dmg})_{2} \cdot 2 \mathrm{Py}$ & $c-c$ & 63 \\
\hline $1 \mathrm{I}$ & $\mathrm{AlEt}_{3} / \mathrm{VO}(\mathrm{acac})_{2}$ & c-c & 60 \\
\hline $3 \mathrm{I}$ & $\mathrm{AlEt}_{3} / \mathrm{Co}(\mathrm{acac})_{2}$ & c-c & 59 \\
\hline $4 \mathrm{I}$ & $\mathrm{AlEt}_{3} / \mathrm{Fe}(\mathrm{acac})_{3}$ & $\mathrm{c}-\mathrm{c}$ & 64 \\
\hline
\end{tabular}

a t-c, trans-cisoidal structure; c-c, cis-cisoidal structure. 
Table V. Powder diffraction data for poly( $\beta$-ethynylnaphthalene) of cis-cisoidal structure $^{\mathrm{a}}$

\begin{tabular}{rr}
\hline$d, \AA^{\mathrm{b}}$ & \multicolumn{1}{c}{$I / I_{1}{ }^{\mathrm{c}}$} \\
\hline 20.83 & 74.26 \\
9.43 & 20.00 \\
5.05 & 100.00 \\
3.52 & 45.71 \\
\hline
\end{tabular}

a Filtered $\mathrm{CuK}_{\alpha}$ radiation.

${ }^{\mathrm{b}} d$, interplanar spacing.

c $I / I_{1}$, relative peak intensity.

(C) (Figure 2) which has no more than 20\% crystallinity (Table IV).

XRD and spectral data show a cis-cisoidal structure for polymer (B) which may exist only as a $3: 1$ helix. This structure may explain the high degree of crystallinity. Figure 2, presents some XRD characteristics of the analysed polymers. One can see that the structure (B) gives a diffractogram (Table $\mathrm{V}$ ) with neat maxima, while the polymer $(\mathrm{C})$ shows only a hollow at about $2 \theta=17^{\circ}$ and a maximum at $2 \theta=7.25^{\circ}$. The polymer (C) obtained by thermal polymerization shows only the hollow of $2 \theta=17^{\circ}$. This means that the structure $(\mathrm{C})$ obtained by catalytic polymerization (less with $\mathrm{AlEt}_{3} / \mathrm{TiCl}_{4}$ ) is characterized by a degree of stereoregularity which is not exhibited by the thermally synthesized polymer. Consequently polymer (A) will have a cis-transoidal structure. This structure allows rotation around single bonds and isomerization in the cis-cisoidal structure in conditions which facilitate the motion of chain segments (in solution or during the polymerization process).

According to NMR studies of cis-cisoidal and trans-cisoidal structural models having three monomer units on a screw, all the protons must appear in the same field. In the case of the cis-transoidal structure having three monomer units on a screw, four protons must be shifted to higher values of $\sigma$, while the transtransoidal structure, with twelve monomer units on a screw, should have two protons shifted to lower values of $\sigma$.

If these findings are true, the structure (C) must be trans-cisoidal (Figure 3e) because only this structure correspond to on NMR spectrum of type (C). The cis-cisoidal structure which exhibits probably the same NMR spectrum is insoluble.

Polymerizations with $\mathrm{Fe}^{\mathrm{II}}(\mathrm{dmg})_{2} \cdot 2 \mathrm{Py} / \mathrm{AlEt}_{3}$, $\mathrm{Me}(\mathrm{acac})_{n} / \mathrm{AlEt}_{3}$ and $\mathrm{TiCl}_{4} / \mathrm{AlEt}_{3}$ lead in the first stage to a cis-transoidal structure (A) which isomerizes into a cis-cisoidal one before the penetration of the propagation chain into the polymer crystallite takes place.

When the polymerization leads directly to a cis-cisoidal conformation, only cyclic trimers can be obtained. The cis-cisoidal structure may be formed only by isomerization of the cistransoidal structure. At the same time polymerization of EN with Ziegler catalytic system leads to the trans-cisoidal structure.

The selectivity of the $\mathrm{TiCl}_{4} / \mathrm{AlEt}_{3}$ catalytic system is given as a function of molar ratio $\mathrm{Al} / \mathrm{Ti}$ for cyclic compounds $(\mathrm{Al} / \mathrm{Ti}=2 / 3)$ or linear polymers $(\mathrm{Al} / \mathrm{Ti}=8) .{ }^{35}$ In the case of ethynylferrocene polymerization with this catalytic system, only cyclic compounds were reported. $^{36}$ On the other hand, Wiley ${ }^{12}$ synthesized $\mathrm{PEN}$ using $\mathrm{TiCl}_{4} / \mathrm{Al}(\mathrm{isoBu})_{3}$ of low molar ratio and obtained only linear poly mers.

Polymerization of EN with the $\mathrm{TiCl}_{4} / \mathrm{AlEt}_{3}$ system of $\mathrm{Al} / \mathrm{Ti}=2 / 3$ and 8 (molar ratio) gave linear polymers of types (B) and (C) (Table II) and 1,3,5-tri( $\beta$-naphthyl)benzene. The NMR spectrum (Figure $3 \mathrm{~b}$ ) of the trans-cisoidal polymer obtained with $\mathrm{TiCl}_{4} / \mathrm{AlEt}_{3}$ system shows a shifting of the naphthalene proton resonances to higher values of $\sigma$ having some common peaks with the NMR spectrum of $1,3,5-\operatorname{tri}(\beta-$ naphthyl)benzene (Figure 3d).

In the UV spectra of this trans-cisoidal structure, three maxima were detected at 290,256, and $234 \mathrm{~m} \mu$ (Figure 4a). Two of these maxima (256 and 290) are specific to the cyclic trimer (Figure 4c). The column chromatography (alumina, $\mathrm{CCl}_{4}$ eluent), separated a white-yellow compound and a brown compound for all transcisoidal (fraction III) polymers obtained with Ziegler catalysts. The IR spectrum of the brown compound is specific to a trans-cisoidal polymer. The UV absorption spectra of brown compounds exhibit only one absorption maximum at 234 $\mathrm{m} \mu$ and a continuous absorption from the UV into the visible region (Figure $4 b$ ). The absorp- 


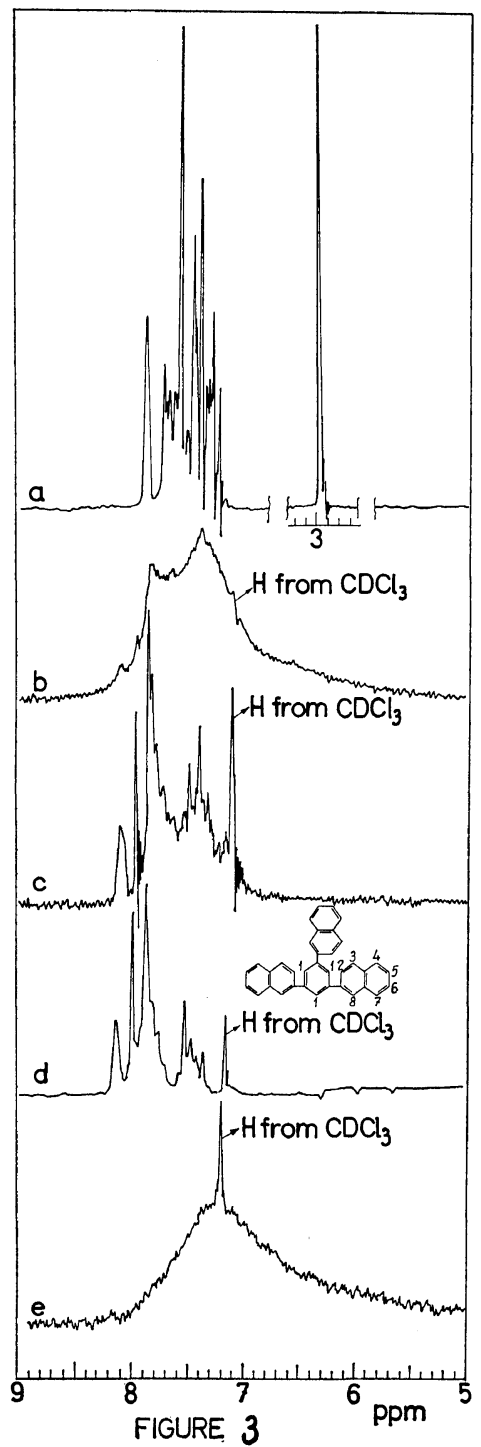

Figure 3. NMR spectra: a, $\beta$-ethyl naphthalene $\left(\mathrm{CCl}_{4}\right) ; \mathrm{b}, \mathrm{PEN}$ of trans-cisoidal structure (No. 23 II) $\left(\mathrm{CDCl}_{3}\right)$; c, white-yellow oligomer separated on column chromatography (No. 22 II) $\left(\mathrm{CDCl}_{3}\right)$; d, 1,3,5-tri( $\beta$-naphthyl)benzene $\left(\mathrm{CDCl}_{3}\right)$; e, PEN of trans-cisoidal structure purified by column chromatography or that obtained by thermal isomerization of cis-cisoidal structure $\left(\mathrm{CDCl}_{3}\right)$.

tion is stronger at shorter wevelengths than at longer wavelengths.

Since the curves are smooth and no discrete maxima appear, no specific chromophore is present in much greater concentration than the others. A curve such as this can be attributed to polymers in which there are a number of chromophores each having different absorption maxima at an even increased wavelength. ${ }^{44}$ This can readily come about in a polymer that has conjugated unsaturation with an evenincreasing number of double bonds in the conjugated sequence. Such a curve would appear as a smooth integration of all the absorption maxima and no maximum would appear separately unless one particular chromophore comprised of a specific number of double bonds dominated the structure of the polymer. The last is the case for the cis-cisoidal structure which, due to the high stereoregularity, has a pronounced inflexion at $550 \mathrm{~m} \mu$ ( $\mathrm{KBr}$ pellet). It means that the cis-cisoidal structure is mainly characterized by chromophores having a number of conjugated double bonds of $\lambda_{\max }$ at $550 \mathrm{~m} \mu$. At the same time the trans-cisoidal structure exhibits an maximum at $370 \mathrm{~m} \mu$ for polymers with maximum at $2 \theta=7.25^{\circ}$.

The NMR spectrum of the above separated

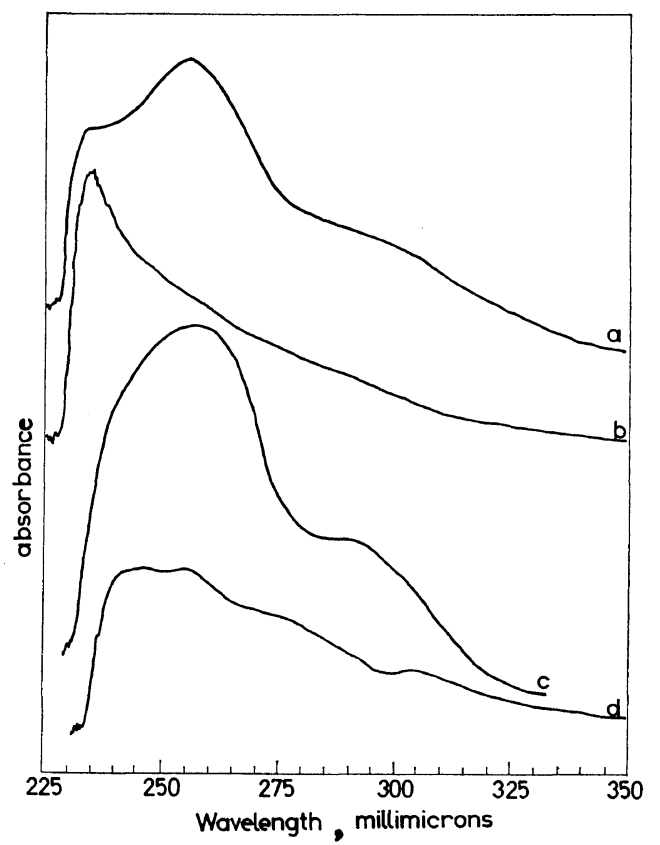

Figure 4. $\mathrm{UV}\left(\mathrm{CH}_{2} \mathrm{Cl}_{2}\right.$ solution $)$ spectra: a, whiteyellow compound separated by chromatography; $b$, linear PEN purified by chromatography; c, 1,3,5-tri( $\beta$-naphthyl)benzene; $d$, typical spectrum for PEN obtained with phosphine catalysts. 
polymers (Figure 3e) exhibits a large resonance due to aromatic and conjugated chain protons between 5.5 and $8.3 \mathrm{ppm}$. This spectrum is specific to acetylenic polymers. ${ }^{36-38}$

The IR spectrum of the white-yellow compound exhibits some similarities (e.g., peaks of 700 and $740 \mathrm{~cm}^{-1}$, Figure 1d) to that of 1,3,5-tri( $\beta$-naphthyl)benzene (Figure 1e). The two maxima of the UV spectrum (256 and 296 $\mathrm{m} \mu$ ), the NMR spectrum (Figure $3 \mathrm{c}$ ) and the IR spectra indicate the white-yellow compound to be $1,3,5$-tri( $\beta$-naphthyl)benzene. The presence in the UV spectrum of 234-m $\mu$ maximum was attributed to the presence of the whiteyellow compounds of the linear polymer. In all trans-cisoidal polymers obtained with Ziegler, arsine, phosphine, and stibine catalysts (fraction III), this cyclic compound was detected on the basis of their electronic spectra.

Based on NMR spectra, the amount of 1,3,5$\operatorname{tri}(\beta$-naphthyl)benzene in polymers could be determined using the following equation.

$$
\begin{aligned}
& \text { Cyclic trimer } \% \\
& =\frac{(\text { peak area of phenyl proton }) \times 7}{\text { (total area of naphthyl proton) }} \times 100
\end{aligned}
$$

The NMR spectrum of 1,3,5-tri( $\beta$-naphthyl)benzene (Figure 3d) shows a sharp singlet at $\sigma=$ $7.98 \mathrm{ppm}$ which is assigned to the phenyl proton of the cyclic trimer. The aromatic multiplets from $7.30-7.52$ and $7.70-7.92 \mathrm{ppm}$ are due to 5- and 6-naphthalene and to 2,3,4,5-naphthalene protons, respectively. The singlet from 8.12 $\mathrm{ppm}$ is due to 8-naphthalene proton. Taking the total area of phenyl protons equal with the area of the singlet of $7.98 \mathrm{ppm}$, the following amounts of the cyclic trimer were obtained for the polymer fractions given in Table II: $46 \%$ for 22 II, $64 \%$ for 22 III, $8 \%$ for 23 II and $28 \%$ for 23 III. These data show the specificity of the $\mathrm{TiCl}_{4} / \mathrm{AlEt}_{3}$ catalytic system in the case of acetylenic derivative polymerization as a function of $\mathrm{Al} / \mathrm{Ti}$ molar ratio.

Perhaps all Ziegler-Natta catalytic system used in this paper act by the same mechanism, that is similarly to the mechanism proposed by Ikeda. ${ }^{39,40}$

The thermal and cationic polymers have also a trans-cisoidal structure.
Thermal Stability of the Poly( $\beta$-ethynylnaphthalene)

With regard to the thermal stability of EN polymers, all structures are stable up to $300^{\circ} \mathrm{C}$ when degradation starts to occur either in air or in nitrogen (Figure 5).

Similarly to other polyacetylenes (4, I), no transitions could be determined from the shape of the DTA curves of the trans-cisoidal structures (Figure 6b). Only an exothermal decomposition could be seen between 500 and $800^{\circ} \mathrm{C}$. Both in air and in a nitrogen atmosphere, the cis-cisoidal structure undergoes an exothermal process at $220^{\circ} \mathrm{C}$ which is not accompanied by weight losses (Figure 6a).

After this process (i.e., at $240^{\circ} \mathrm{C}$ ) the compound turned to a soluble and amorphous polymer which exhibited IR, UV, and NMR spectra

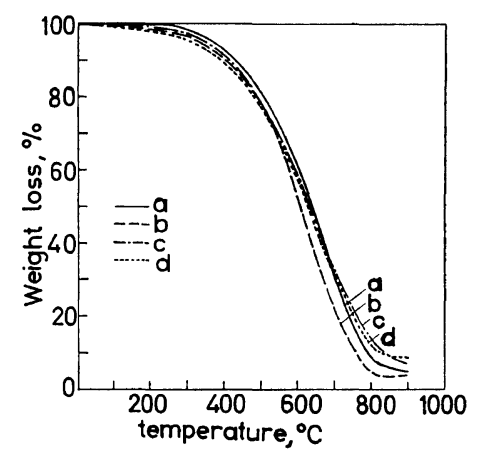

Figure 5. The weight loss curves: a, PEN of cis-cisoidal structure (No. $13 \mathrm{I}) ; \mathrm{b}$, PEN of transcisoidal structure (No. 13 III); c, PEN of transcisoidal structure (No. $23 \mathrm{II}$ ); d, PEN of transcisoidal structure (No. 30 II).

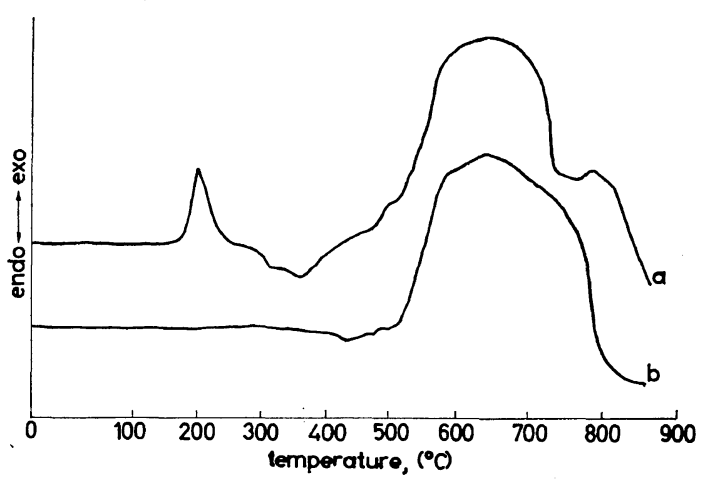

Figure 6. Typical DTA curves: a, PEN of ciscisoidal structure (No. 13 I); b, PEN of transcisoidal structure (No. $30 \mathrm{II}$ ). 


\section{Cr. Simionescu, Sv. Dumitrescu, and V. Percec}

specific to trans-cisoidal structure $\left(\mathrm{mp} 160^{\circ} \mathrm{C}\right.$, $\bar{M}_{n}=783$ ).

In conclusion, at $220^{\circ} \mathrm{C}$ an order-disorder transition takes place and it is accompanied by loss of crystallinity. During this process the isomerization of cis-cisoidal structure to a transcisoidal one occurs. This isomerization can explain the exothermic nature of the process. This is the first transition of this kind observed for acetylenic polymers.

An order-disorder transition was noted in the highly crystalline polyphenylacetylene but without any indications as to its nature..$^{45,46}$

Our last results on synthesis, structure and properties of different isomeric $N$-ethynylcarbazole polymers, ${ }^{47}$ polyphenylacetylene and poly $(\alpha \text {-ethynylnaphthalene })^{43}$ have indicated that the order-disorder phenomenon observed by Ehrlich in the case of crystalline polyphenylacetylene $e^{45,46}$ represents in fact a structural isomerization similar to that of PEN, i.e., the cis-trans isomerization.

\section{REFERENCES}

1. Cr. Simionescu, Sv. Dumitrescu, and V. Percec, to be published in Polymer $\mathbf{J}$.

2. G. Natta, G. Mazzanti, and R. Corradini, Rend. Accad. Nazl. Lincei, 25(8), 2 (1958).

3. W. H. Watson, Jr., W. C. McMordie, Jr., and L. G. Lands, J. Polym. Sci., 55, 137 (1961).

4. F. D. Kleist and N. R. Byrd, ibid., Part A-1, 7, 3419 (1969).

5. S. Ikeda, Kogyo Kagaku Zasshi (J. Chem. Soc. Japan, Ind. Chem. Sect.), 70, 188 (1967).

6. H. Shirakawa and S. Ikeda, Polymer J., 2, 231 (1971).

7. R. J. Kern, J. Polym. Sci., Part A-1, 7, 621 (1969).

8. Cr. Simionescu, Sv. Dumitrescu, I. Negulescu, V. Percec, M. Grigoraș, I. Diaconu, M. Leancă, and L. Goraș, Vysokomol. Soedin., 4, 790 (1974).

9. M. I. Kushnerev, G. I. Bantirev, M. I. Cerkashin, and A. A. Berlin, Izv. Akad. Nauk. SSSR, ser. Him, 2291 (1971).

10. G. I. Bantirev, M. I. Cerkashin, I. D. Kalihman, and A. A. Berlin, Himia Atzetilena, Nauka, Moskwa, 1972, p 326.

11. Cr. Simionescu, Sv. Dumitrescu, V. Percec, I. Negulescu, and I. Diaconu, J. Polym. Sci., Polym. Symp. Ed., No. 42, 201 (1973).

12. R. H. Wiley and J. Y. Lee, J. Macromol. Sci.-
Chem., A5, 507 (1971).

13. J. Robin, Ann. Chim., 16, 428 (1931).

14. H. F. Bassilios and A. Y. Salem, Bull. Soc. Chim. France, 586 (1952).

15. H. O. Wirth, W. Kern, and E. Schmitz, Makromol. Chem., 68, 69 (1963).

16. L. Tschugaeff, $Z$. Anorg. Allgen. Chem., 46, 144 (1905).

17. “Inorganic Synthesis,"' Vol. V, T. Moeller, Ed., McGraw-Hill, New York, N.Y., 1955, p 114.

18. T. R. Crompton, Analyst, 91, 374 (1966).

19. L. M. Venanzi, J. Chem. Soc., 719 (1958).

20. U. S. Patent, 3054775 (1962).

21. K. A. Jensen, Z. Anorg. Allg. Chem., 229, 228 (1936).

22. J. A. Osborn, F. H. Jordine, J. F. Yung, and G. Wilkinson, J. Chem. Soc., Sect. A, 1712 (1966).

23. H. Itanami and J. C. Bailar, Jr., J. Amer. Oil Chem. Soc., 44, 147 (1967).

24. F. G. Mann, J. Chem. Soc., 1549 (1954).

25. H. A. Tayim, A. Bouldoukian, and F. Awad, J. Inorg. Nucl. Chem., 32, 3799 (1970).

26. K. A. Jensen, Z. Anorg. Allg. Chem., 229, 265 (1936).

27. A. D. Allen and M. C. Baird, Chem. Ind. (London), 139 (1965).

28. L. Malatesta and C. Cariello, J. Chem. Soc., 2323 (1958).

29. H. A. Tayim, S. K. Thabet, and M. U. Karkanawi, J. Inorg. Nucl. Chem, Letts, 8, 235 (1972).

30. I. Collamati and A. Furlani, J. Organometal. Chem., 17, 457 (1969).

31. Cr. Simionescu, Sv. Dumitrescu, V. Percec, and L. Goraş, unpublished data.

32. H. Masai, K. Sonogashira, and N. Hagihara, Bull. Chem. Soc. Japan, 8, 2226 (1971).

33. H. Masai, K. Sonogashira, and N. Hagihara, J. Organometal. Chem., 34, 397 (1972).

34. W. Mareoni, A. Mazzei, G. Lugli, and M. Bruzzone, J. Polym. Sci., Part C, No. 16, 805 (1967).

35. A. Furlani Donda, E. Cervone, and M. A. Biancifiori, Recueil Trav. Chim., 81, 585 (1962).

36. T. Nakashima, T. Kunitake, and C. Aso, Makromol. Chem., 157, 73 (1972).

37. Cr. Simionescu, Sv. Duitrescu, and V. Percec, ibid., 157, 75 (1972).

38. C. Aso, T. Kunitake, and K. Saiki, ibid., 151, 265 (1972).

39. S. Ikeda and A. Tamaki, Intern. Symp. Macromol. Chem. Tokyo-Kyoto, Preprint I-124 (1966).

40. S. Ikeda and A. Tamaki, J. Polym. Sci., Part $B, 4,605$ (1966). 
The Polymerization of Acetylenic Derivatives. XXV

41. D. B. Ludlum, A.W. Anderson, and C. E. 45. P. Ehrlich, J. Macromol. Sci.-Phys., B2, 153 Ashby, J. Amer. Chem. Soc., 80, 1380 (1958). (1968).

42. Cr. Simionescu, Sv. Dumitrescu, S. Vasiliu, and V. Percec, J. Thermal Analysis, 6, 389 (1974).

43. Cr. Simionescu, Sv. Dumitrescu, and V. Percec, unpublished data.

44. P. E. Platz, J. Polym. Sci., Part C, No. 4, 1335 (1964).

46. G. M. Holob, P. Ehrlich, and R. D. Allendoerfer, Macromolecules, 5, 569 (1972).

47. Cr. Simionescu, Sv. Dumitrescu, and V. Percec, XXIIIth Intern. Symp. Macromol., Madrid, Preprint I, 1974, p 333. 